Paper:

\title{
The 1755 Lisbon Tsunami at Vila do Bispo Municipality, Portugal
}

\author{
Angela Santos* and Shunichi Koshimura** \\ * Centre for Geographical Studies, Institute of Geography and Spatial Planning, Universidade de Lisboa \\ Rua Branca Edmée Marques,1600-276 Lisboa, Portugal \\ E-mail: angela.santos@campus.ul.pt \\ ** International Research Institute of Disaster Science, Tohoku University \\ Aoba 6-6-03, Aramaki, Aoba-ku, Sendai 980-8579, Japan \\ [Received June 3, 2015; accepted September 16, 2015]
}

\begin{abstract}
The numerical model of the 1755 Lisbon Tsunami was conducted at Vila do Bispo municipality. The tsunami source area of this historical event is assumed to be on the Gorringe Bank. Numerical model results of historical data have been validated by a combined analysis of eyewitnesses' accounts, field surveys, geological records and archeological findings (conducted by previous authors). The coastal area has remained a mostly natural landscape since the $18^{\text {th }}$ century, with popular beaches that increase the population potentially exposed to a tsunami, especially one occurring in summer. For these reasons, we use local tsunami hazard assessment as a criterion varying between moderate and critical. Results also show that the $\mathbf{1 6}$ low ground areas we surveyed were inundated between 15 and 30 minutes after the earthquake. For this reason, persons should act quickly in future to evacuate areas immediately after an earthquake and to move to higher ground. Results also show that safe, swift evacuation may be difficult in $50 \%$ of these areas, endangering special populations such as tourists. Tsunami information boards should therefore be put on beaches and evacuation exercises and drills should be implemented and practiced regularly.
\end{abstract}

Keywords: 1755 Lisbon Tsunami, numerical model, field survey, tsunami hazard

\section{Introduction}

Our focus in this paper is on the historical 1755 Lisbon Tsunami, despite the many uncertainties involved. This tsunami should be studied because it is the worst-case scenario of such an event in the Atlantic Ocean [1]. One issue is identifying the tsunami source area because the seismotectonic areas off the shores of Portugal are complex, as has been summarized and discussed [2]. While many authors over the centuries have studied this historical event, the most complete compilation of historical accounts in Portugal was conducted by Francisco Luiz Pereira de Sousa and published in four volumes over 13 years [3-6]. As a geologist, Sousa also combined the eyewitnesses' accounts of earthquake damage and local soil types to classify seismic intensity. The epicenter was later

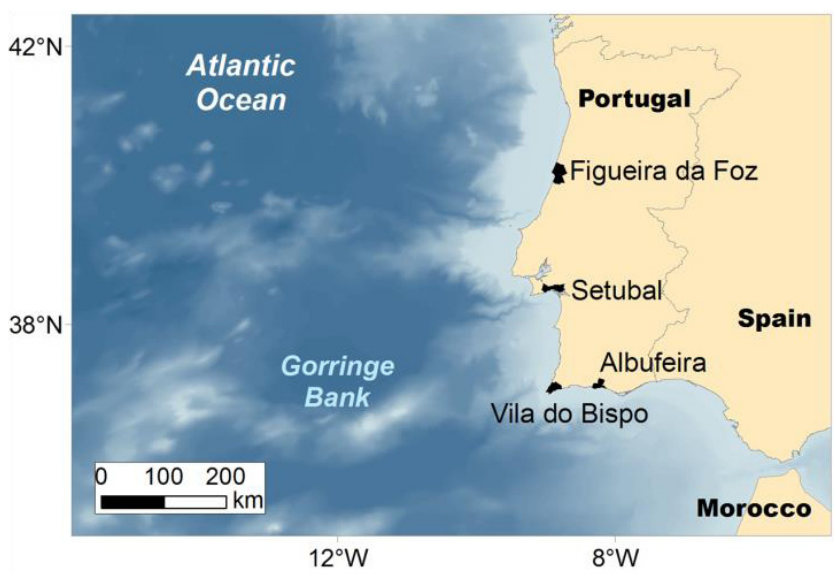

Fig. 1. Location of municipalities on which the tsunami numerical model was carried out at the local scale.

proposed to have been located on the Gorringe Bank [7], a bathymetry structure about $130 \mathrm{~km}$ southeast of Portugal (Fig. 1). This proposal was based mostly on the work of Sousa. More recently, seismic intensity modeling conducted [8] also supported the Gorringe Bank source model. Although several authors have tried using numerical modeling to piece together this historical event, the first successful results were obtained by [2]. We considered the Gorringe Bank source area (Fig. 1) by using a tsunami numerical model on a regional scale based on a reevaluation of tsunami travel time reported in historical accounts and combined with geological records in the UK [9-11] and the presence of turbidities near the Gorringe Bank [12,13].

Following this major breakthrough, several studies have considered a source model [2] of the numerical model of the 1755 Lisbon Tsunami on a local scale in Portugal (Fig. 1) at Figueira da Foz, Setubal, Vila do Bispo and Albufeira.

At Figueira da Foz, historical accounts report an un-

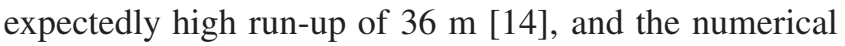
model showed there was indeed there was a local amplification at the Figueira da Foz beach [15]. In urban Setubal (Fig. 1), historical accounts report three major waves validating the numerical model, which provided three major waves [16]. The vulnerability of buildings assessed at Setubal showed the most vulnerable buildings to be located 


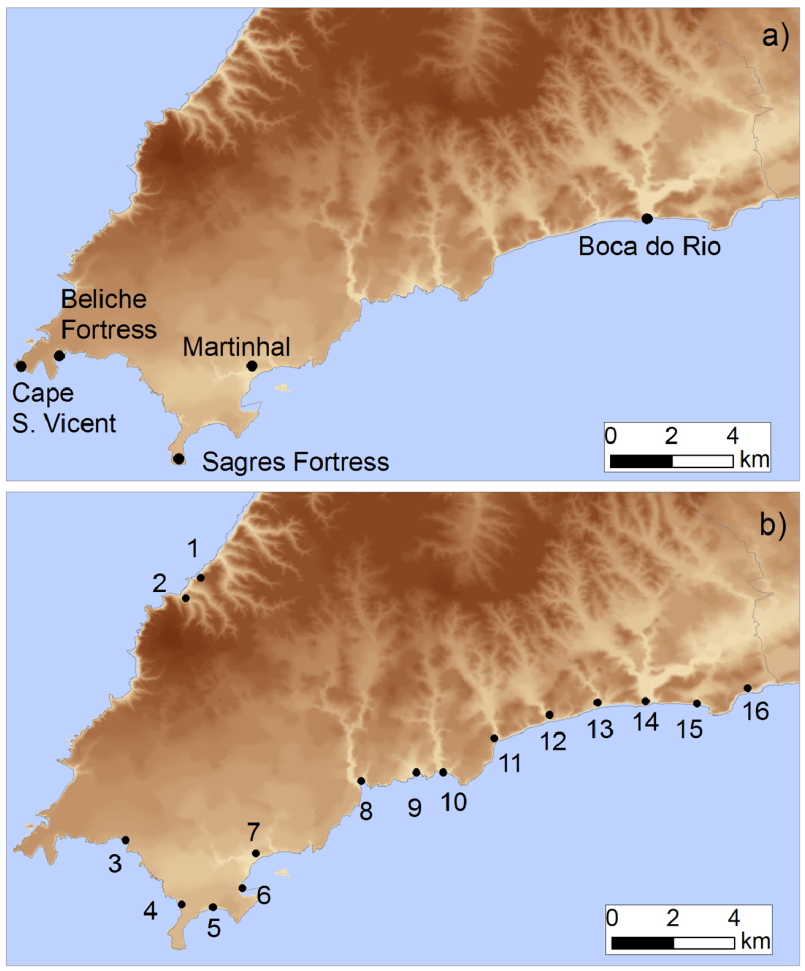

Fig. 2. Vila do Bispo municipality: a) places with historical accounts; b) beaches at Cordoama (1), Castelejo (2), Beliche (3), Tonel (4), Mareta (5); Port of Baleeira (6), Martinhal (7), Barranco (8), Ingrina (9), Zavial (10), Furnas (11), Figueira (12), Salema (13), Boca do Rio (14), Cabanas Velhas (15) and Burgau (16).

at east and west of the city [17], as was also validated by eyewitnesses' reports of major damage in these neighborhoods, rather than in the central area [16]. At Albufeira (Fig. 1), the tsunami numerical model showed that three major waves hit the area [1], which also agreed with historical accounts.

At the municipality of Vila do Bispo (Fig. 1), very complete historical accounts report the tsunami at five places, as shown in Fig. 2a, i.e., Cape Sao Vincent, Beliche Fortress, Sagres Fortresses, Martinhal and Boca do Rio.Geological tsunami records also exist at Martinhal up to $400 \mathrm{~m}$ inland [18] and about $1 \mathrm{~km}$ at Boca do Rio [1921]. Vila do Bispo is the municipality closest to the tsunami source area. Since the $18^{\text {th }}$ century, the municipality has developed, although the coastline itself has remained a natural landscape, except for construction of the fishing port of Baleeira (Point 6 in Fig. 2b). It should also be noted that the coastline population is exposed to potential tsunamis at 15 popular local beaches during the summer and during surfing and windsurfing all year around (Fig. 2b). Although the frequency of large earthquakes and tsunamis in Portugal is quite low [22], it is important to understand the potential impact of a tsunami scenario on the modern municipality.

We therefore conducted a field survey at Vila do Bispo in 2007, and on several occasions during 2011-2015 based on post tsunami field survey techniques [23-25]. The purpose of the survey was to collect photos and
GPS data to validate eyewitnesses' accounts by identifying landmarks existing today. We used collected data to construct numerical model regions 4 and 5.

The survey also enabled us to identify tsunami evacuation paths. During an evacuation exercise conducted at the Lisbon University campus [26], the average walking velocity was measured at $0.94 \mathrm{~m} / \mathrm{s}$, which agreed with other research, which measured average velocities of 0.9 $1.0 \mathrm{~m} / \mathrm{s}$ [27]. For evacuation purposes in this study, these velocities are taken into consideration.

Our study objectives were to a) validate the tsunami source model proposed by [2]. The tsunami numerical model at Vila do Bispo municipality will be carried out, in order to reproduce the tsunami parameters as reported by eyewitnesses' accounts and geological records. Studies have showed the importance of this kind of approach in validating the tsunami model in a historical event [28, 29]. The numerical model results will be complemented with the use of historical maps combined with field survey, b) obtain detailed inundation areas at the beaches by carrying out the tsunami numerical model with modern topography, and to c) conduct local tsunami hazard assessment at Vila do Bispo to which a criterion [15] was applied.

We hope that this study will contribute to a more complete, realistic interpretation of 1755 Lisbon Tsunami features and to identifying key points enabling safer, swifter evacuation from coastlines such as that at Vila do Bispo.

\section{Historical Accounts and Field Survey}

In the collection and interpretation of historical accounts conducted by [14], we used accounts providing tsunami parameters such as travel time, initial response, run-up and the number of waves, as summarized in Table 1. Historical accounts provide numerous clues about the tsunami at Vila do Bispo, including inundation extension (Table 1). Eyewitnesses reported the tsunami using old Portuguese measurements, so we converted these as follows: 1 braça $=1.8 \mathrm{~m}$; 1 league $=4500 \mathrm{~m}$ [30]. The location of places where eyewitnesses were during the event is shown in Fig. 2a. Initial response and inundation extension values are as follows:

\section{Cape Sao Vicente:}

"From the North, it decreased about 6 braças (10.8 m), (but) it did not move from its limits. From the East at a distance of $1 / 2$ league $(2250 \mathrm{~m})$ to the sea and a depth of 8 braças $(14 \mathrm{~m})$, everything became dry." $[31,3]$

\section{Sagres fortress:}

"The sea withdrew about $1 / 2$ league $(2250 \mathrm{~m})$, leaving inlets dry where big ships anchored." $[31,3]$

\section{Martinhal:}

"(The sea) entered (...) a space of $1 / 2$ legoa $(2250 \mathrm{~m})$, tearing away the vineyards and leaving the land like a beach with several fishes, many big stones 
Table 1. Tsunami parameters compiled from [14], excluding the inundation extension. (1) At the cliffs.

\begin{tabular}{|c|c|c|c|c|c|}
\hline Place & $\begin{array}{l}\text { Travel time } \\
\quad(\min )\end{array}$ & Initial response & $\begin{array}{c}\text { Inundation } \\
\text { extension }(\mathrm{m})\end{array}$ & Run-up (m) & $\begin{array}{l}\text { Number } \\
\text { of waves }\end{array}$ \\
\hline Cape Sao Vincent & $\begin{array}{c}6-7 \\
16-17\end{array}$ & $\begin{array}{l}\text { Subsidence } \\
\text { Uplift }\end{array}$ & $\begin{array}{c}\text { East: }-2250 \\
-\end{array}$ & $\begin{array}{c}\text { North: }-11 \text {; East: }-14 \\
-\end{array}$ & - \\
\hline Beliche Fortress & - & - & - & $+54(1)$ & 3 \\
\hline Sagres Fortress & $\begin{array}{l}- \\
-\end{array}$ & $\begin{array}{l}\text { Subsidence } \\
\text { Uplift }\end{array}$ & $\begin{array}{c}\text { West: }-2250 \\
-\end{array}$ & North: $+108 ;$ East: $+144(1)$ & - \\
\hline Martinhal & - & - & +2250 & - & 3 \\
\hline Boca do Rio & - & Uplift & +2250 & $+10-12$ & - \\
\hline
\end{tabular}

(...) The flux and reflux were repeated three times, the first one being the largest." [31,3]

\section{Boca do Rio:}

"It uncovered foundations of a large settlement that extended farther seawards (...]." [31,3]. "The sea invaded (...) for more than $1 / 2$ legoa $(2250 \mathrm{~m})(. .$.$) .$ The backrush uncovered great and noble buildings of which no memory existed." [3]

In general, the coastal areas of Vila do Bispo have remained natural landscape - the only significant difference being the construction of Baleeira port (Point 6 in Fig. 2b). A comparison between a historical map [32] and modern data shows a $15 \mathrm{~m}$ bathymetric contour line to be located at about $500 \mathrm{~m}$ from the coastline, not at $2 \mathrm{~km}$, as eyewitnesses reported at Cape Sao Vincent. The historical map dates back to 134 years after the tsunami, but nevertheless is the oldest map of the area found thus far. It can therefore only be speculated that before the 1755 Lisbon tsunami, the local bathymetry at the bay between Cape Sao Vincent and Sagres was very shallow and because of this, large ships would have to anchor about $2 \mathrm{~km}$ from the coast as reported by the eyewitness at Sagres fortress.

Still, the historical map is suitable for historically validating the 1755 Lisbon tsunami because several landmarks on the map still exist today. We used these landmarks to construct the DEM of regions 4 and 5 of the numerical model, as explained in the next section (Fig. 6d). The Sao Vincent lighthouse (Fig. 3a) has existed most probably since 1520 . In 1587, the English sea captain and pirate Sir Frances Drake attacked the area, destroying the tower, which was then restored only in 1606 [33]. Historical accounts reported that the facility was also used as a convent [31], so it appears probable that the local population and therefore eyewitnesses could have witnessed the tsunami themselves. In 1846, the lighthouse underwent a major renovation, and because it has been an important landmark, it was pointed out on the historical map [32]. The field survey showed that Cape Sao Vincent was at $63 \mathrm{~m}$ high.

Eyewitnesses reported that the tsunami reached the rocks of the Beliche Fortress, also indicated on the historical map [32]. The fortress was damaged in the 1755 earthquake, deteriorating over time. Restoration work is being conducted on the monument, as we were allowed to see. The patio (Fig. 3b) has a wide view of the bay
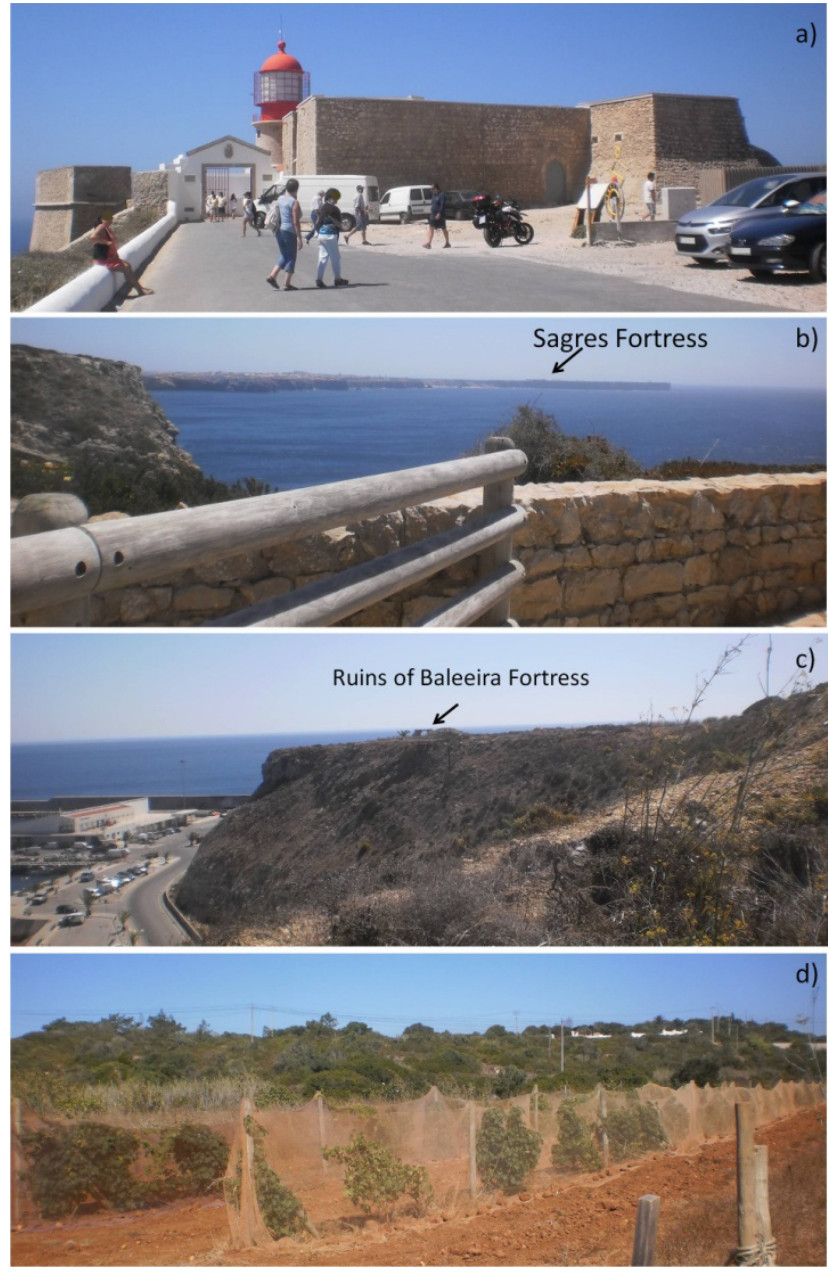

Fig. 3. Field survey at Vila do Bispo: a) Sao Vincent lighthouse; b) view from Beliche Fortress; c) Baleeira fortress; d) vineyards at Martinhal.

confirming eyewitness reports that they had seen tsunami waves coming and receding. GPS measurements showed the area to be at $51 \mathrm{~m}$ high, also validating reports that tsunami waves reached the rocks of the fortress at $54 \mathrm{~m}$ high.

There were 181 persons at the Sagres fortress when the earthquake struck,[31] and they reported extreme tsunami run-up of over $100 \mathrm{~m}$ high (Table 1). This extreme feature was confirmed during the 2014 Hercules storm, which was pointed out as a meteotsunami [34]. During 

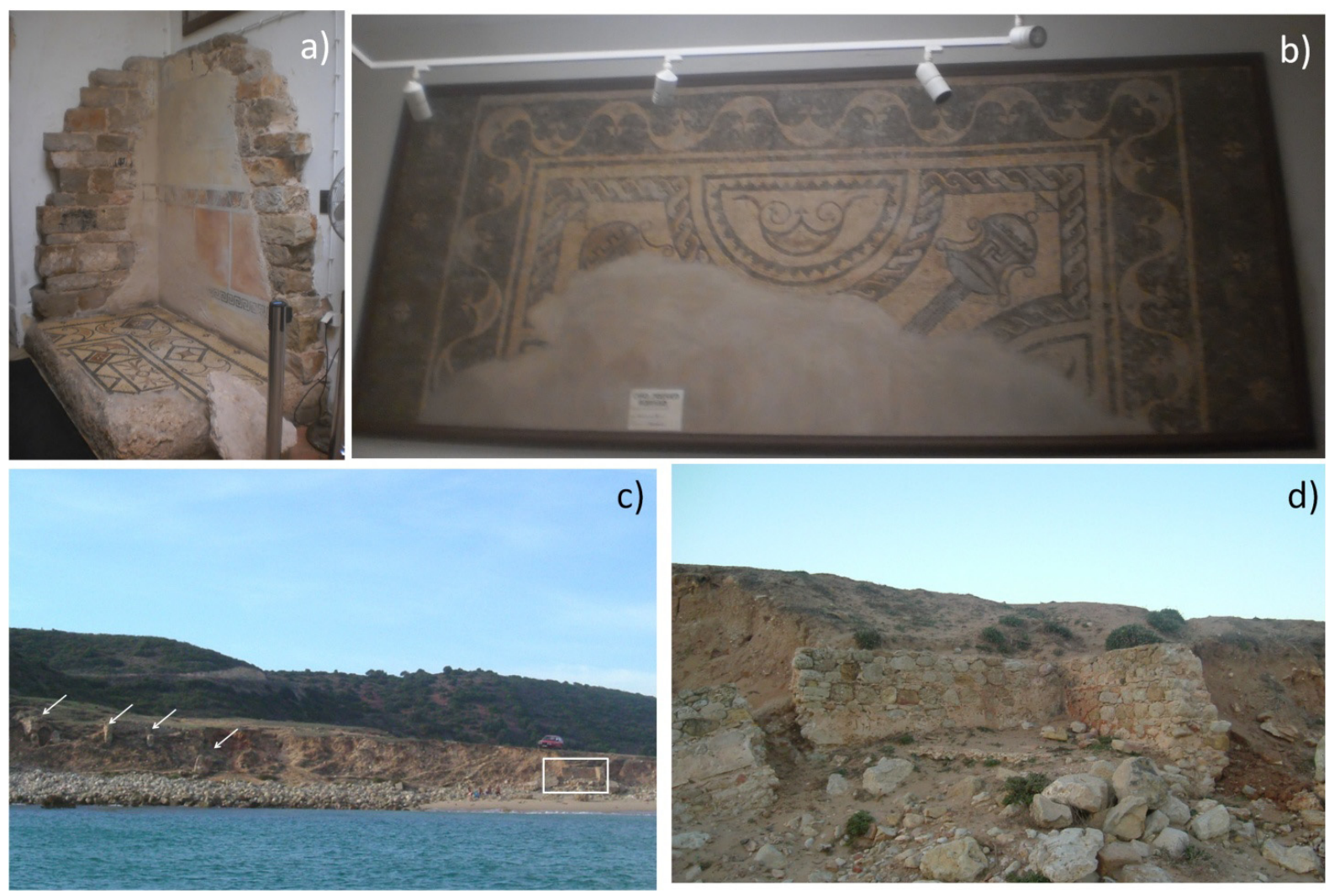

Fig. 4. Field survey at Boca do Rio 4: a) original mosaic (Lagos Municipal Museum photo taken on September 8, 2014); b) floor mosaic (Lagos Municipal Museum; photo taken on September 8, 2014); c) view of Boca do Rio beach. Only a few walls remain from the Roman complex (photo taken on November 27, 2007); d) detailed ruins of a room (photo taken on November 27, 2007).

this event, significant amplifications were observed at the cliffs of Beliche and Sagres fortresses, confirming historical accounts. In fact, run-up was about $60 \mathrm{~m}$ high at Sagres [35]. Our field survey showed the area to be located at $31-37 \mathrm{~m}$ high.

Baleeira fortress was significantly damaged in the 1755 Earthquake and been in ruins ever since (Fig. 3c). This landmark is indicated on the historical map [32] as located at about $31 \mathrm{~m}$ high.

Our survey at Martinhal showed that the vineyards still exist today (Fig. 3d). Their present location is at about $7 \mathrm{~m}$ high, about $1 \mathrm{~km}$ inland from the beach. The area has not changed significantly since the $18^{\text {th }}$ century, showing the approximate location of vineyards destroyed by the 1755 tsunami. It is very likely, however, that the vineyards were relocated to slightly higher ground after the tsunami due to the salty content of the soil. The area is quite small for industrial farmland, showing that cultivation is still most likely for family consumption, not for industrial wine production. The low resistance of the plants used in the $18^{\text {th }}$ century, combined with the area's poor soil and local manual agricultural techniques would result in roots reaching only a shallow $0.5 \mathrm{~m}$ deep, so tsunami waves would easily have torn plants up. The lowest inland area of Martinhal is at about $4.66 \mathrm{~m}$ high, thus providing a reasonable path for the tsunami to reach the vineyards.

The Boca do Rio site is a low flat valley surrounded by high ground offering a view safe from the tsunami.
Eyewitnesses reported that the tsunami uncovered an unknown coastline settlement. The first archeological exploration was conducted by archeologist Estacio da Veiga in April 1878 [36-38], who identified the findings as a Roman settlement. During his exploration, Veiga drew a plan of the complex buildings showing that coastline erosion was already damaging buildings. He also drew the complete floor mosaics of two rooms, published finally in 1910. Field work continued, but further data was published only in 1953 [36]. In a 1933 campaign, Roman mosaics and others artifacts were removed from the site near the beach and transported to the Lagos Museum (Figs. 4a, b), where they remain today. Fig. 4a shows a reconstruction of the corner of a room. Fig. $4 \mathbf{b}$ shows a panel with less than $50 \%$ of the original mosaic. The exploration at Boca do Rio has continued, with new findings in 1982 [37]. Other campaigns were conducted in 2003 and 2005 [38]. Natural coastal erosion damaged the Roman settlement significantly at Boca do Rio beach [39]. As of November 2007 (Figs. 4c, d), only a few walls remain. Our local field survey shows the Boca do Rio barrier, where the Roman ruins stand at about $7 \mathrm{~m}$ high; the low area of Boca do Rio is at about 3-4 m high.

\section{Tsunami Numerical Model Setting}

Sea surface displacement was calculated based on fault parameters [2] with the source dimensions of $200 \mathrm{~km}$ by 


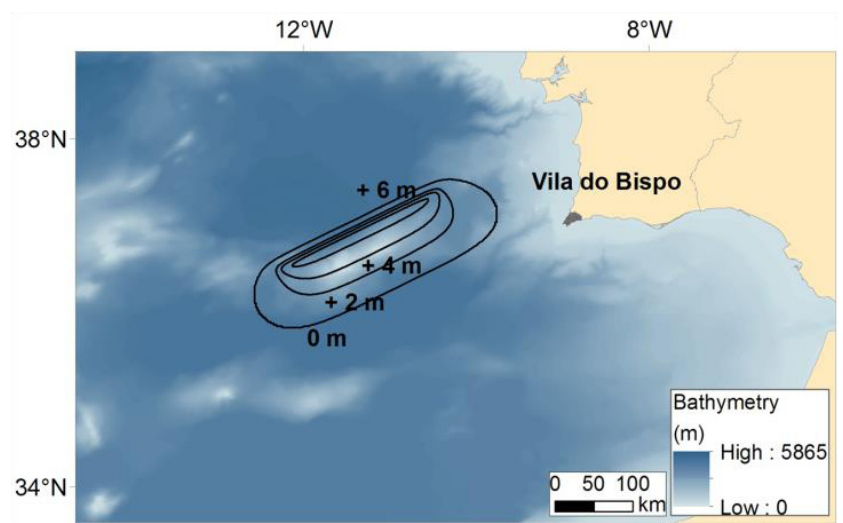

Fig. 5. Initial sea surface displacement.

$80 \mathrm{~km}$ [40], and using [42] formulas. Maximum uplift is +6 m (Fig. 5).

To calculate the tsunami-inundated areas, we used nonlinear shallow-water equations discretized with a staggered leap-frog scheme [41]. We applied the numerical model to a five-region nesting in which regions have progressively smaller areas and finer cell grids and are included in previous regions as shown in Fig. 5. This has been applied in several tsunami numerical modeling studies [43]. The first successful local numerical model validation, at Vila do Bispo, was obtained [1,44] focusing on Boca do Rio (Fig. 2b). The cell-size grid in the final region of the numerical model was $25 \mathrm{~m}$ and maximum local depth was about $58 \mathrm{~m}$. Considering the entire municipality area, however, we found the following two difficulties:

(i) The first difficulty involves the size of the final $25 \mathrm{~m}$ cell grid was not precise enough to reproduce tsunami behavior at Vila do Bispo accurately due to the area's many inlets, bays, islets, and narrow beaches surrounded by high cliffs. To deal with this, we found by trial and error that the grid most suitable for final calculation was $10 \mathrm{~m}$, so the first region is the widest, with a cell 810 m (Table 2). Region 2 has a cell $270 \mathrm{~m}$ in size and region 3's is $90 \mathrm{~m}$. Region 4 , which is $30 \mathrm{~m}$ in size, and region 5 , which is $10 \mathrm{~m}$ in size, show details of coastal zones and topography. The numerical model nesting regions are shown in Fig. 6. Cell sizes agree with Courant-FriedrichsLewy (CFL) conditions (Table 2) to ensure numerical model stability.

(ii) The second difficulty involves bathymetry data [45], which are 1-minute cell size. After resampling data at $810 \mathrm{~m}$, region 1 showed atypical tsunami behavior. Portugal's offshore bathymetry is very complicated and has several structures, including seamounts, plateaus and banks surrounded by deep abyssal plains and canyons. In some cases, these structures are so close to the coastline that they make numerical modeling extremely difficult. The Mazagan Plateau and the Dacia Bank are continuous sources of instabilities in region 1 , as are the Desco-
Table 2. Cell size (Dx) and CFL number in each nesting region.

\begin{tabular}{lrrrrr}
\hline & R1 & R2 & R3 & R4 & R5 \\
\hline Dx (m) & 810 & 270 & 90 & 30 & 10 \\
CFL & 0.10 & 0.28 & 0.60 & 0.42 & 0.95 \\
\hline
\end{tabular}

bridores Seamounts in regions 1-3, even if CFL conditions were satisfied (Table 2). Even conducting new simulation tests with new GEBCO bathymetry data, which have $30 \mathrm{sec}$ cell grids, did not significantly improve numerical model results.

The main region 1 bathymetry features are the Galicia bank (Fig. 6a), with its top at $800 \mathrm{~m}$ deep and over $30 \mathrm{~km}$ diameter. The Tore-Madeira Rise, between the Tore Seamount and Madeira Islands, has several seamounts between 1000 and $2000 \mathrm{~m}$ deep. The shallowest is the Josephine Seamount, which is $200 \mathrm{~m}$ deep. The Gorringe Bank, which is almost rectangular and $200 \times 80 \mathrm{~km}$, has two main seamounts that are the shallowest in the entire region - the Gettysburg Seamount, which reaches about $25 \mathrm{~m}$ deep, and the Ormonde Seamount, which is $48 \mathrm{~m}$ deep. The Mazagan Plateau near the Moroccan coastline is $20 \mathrm{~km}$ wide and $1200 \mathrm{~m}$ deep. The top of the Dacia Bank is $6 \mathrm{~km}$ in diameter and reaches $200 \mathrm{~m}$ deep. The Descobridores Seamounts consist of three small mountains - Pedro Estobar, $132 \mathrm{~m}$ deep and $1 \mathrm{~km}$ wide; Estevao Gomes, $160 \mathrm{~m}$ deep and 2,300 m wide; and Fernao Gomes, $400 \mathrm{~m}$ deep and $460 \mathrm{~m}$ wide - immediately north of Sao Vincent Canyon, which is 1,200 m deep near the seamounts (reaching a maximum of 3,800 m deep) and about $14 \mathrm{~km}$ wide.

The major region 2 and 3 bathymetry structures are the Principes de Aviz Seamounts, which consist of three small mountains - Infante S. Pedro, $469 \mathrm{~m}$ deep and about $1 \mathrm{~km}$ wide; Infante Santo, $400 \mathrm{~m}$ deep and about $3 \mathrm{~km}$ wide; and Infante D. Henrique, $400 \mathrm{~m}$ deep and about $1.5 \mathrm{~km}$ wide. The Rincao da Lebre canyon ranges from 2000 to $3800 \mathrm{~m}$ deep and is about $40 \mathrm{~km}$ wide. The triangular Sagres Plateau is $600-800 \mathrm{~m}$ deep and about $30 \mathrm{~km}$ on each side. The Cama da Vaca de Fora (CVF) Sea is 200$700 \mathrm{~m}$ deep and makes sharp turns at angles of about $90^{\circ}$. The roughly rectangular Lagos Plateau is 700-800 m deep and about $12 \mathrm{~km}$ wide by $20 \mathrm{~km}$ long.

Regions 4 and 5 have no major bathymetry structures. The proximity of deep bathymetry to the coastline, however, provides a difficult selection of the area to ensure numerical model stability. In region 5, the CFL is 0.95 , which is at the edge of stability conditions.

To deal with these conditions, we built region 1 by combining [45] and the original bathymetric chart [46] used to contribute to GEBCO off the shore of Portugal. Because the chart format was paper, we manually digitized it in an ArcGIS environment. The original chart is $1: 1,000,000$, and the accuracy of data enabled us to construct bathymetry data ranging from 600 to $800 \mathrm{~m}$ in cell size grids, which were suitable for the $810 \mathrm{~m}$ cell size considered for region 1. During the digitization process, which took about two years to complete, we tested sev- 

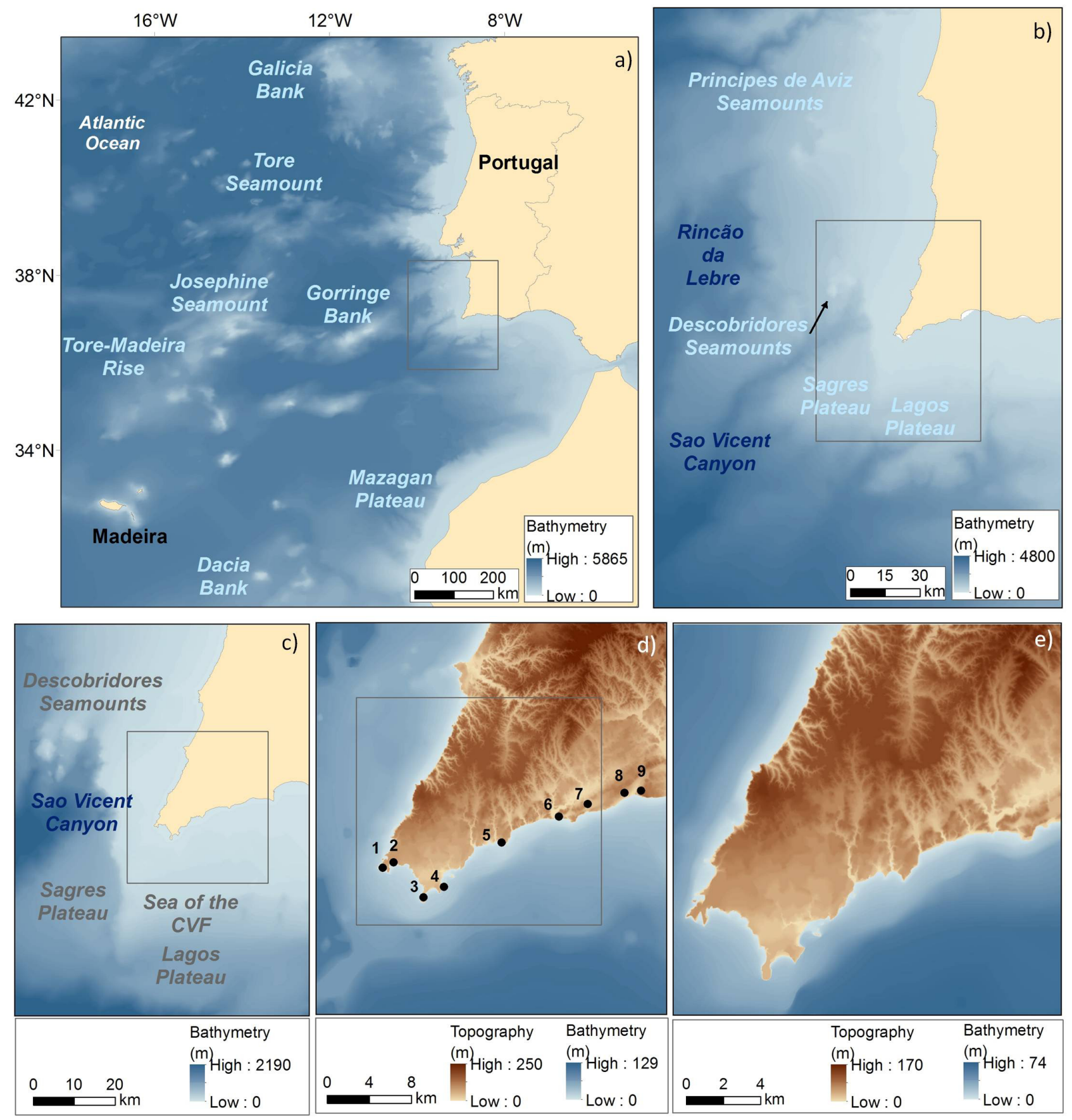

Fig. 6. Numerical model nesting: a) main region with a cell size of $810 \mathrm{~m}$; b) region 2 with a cell size of $270 \mathrm{~m}$; c) region 3 with a cell size grid of $90 \mathrm{~m}$. Abreviation: Cama da Vaca de Fora (CVF) Sea; d) region 4 with a cell size grid of $30 \mathrm{~m}$. Landmarks used to digitize historical maps: 1 Sao Vincent light house, 2 Beliche Fortress, 3 Sagres Fortress, 4 Baleeira Fortress, 5 Zavial Fortress, 6 Almadna Fortress, 7 Burgau (GPS) Station, 8 Sra da Luz church, 9 Atalaia (GPS) Station, and e) region 5 with a cell size grid of $10 \mathrm{~m}$.

eral simulations showing an improvement in the numerical model response. After digitization was completed, the numerical model for region 1 had a good response and tsunami propagation behaved the same as in [2]. ${ }^{1}$

We had several bathymetry charts for constructing regions 2 and 3 manually digitized [47], also in an ArcGIS environment. The setting of both regions took about one

1. For animation, see https://sites.google.com/a/campus.ul.pt/tsurima/ publications. year to complete.

We used bathymetry data [47] and modern topography maps $[48,49]$ to construct regions 4 and 5 , together with a historical map [32] to conduct historical validation.

This was digitized by combining field survey data and the nine landmarks on the historical map (Fig. 6d). The numerical model setting of regions 4 and 5 took about two years to complete.

The numerical model has been run over 350 times. 

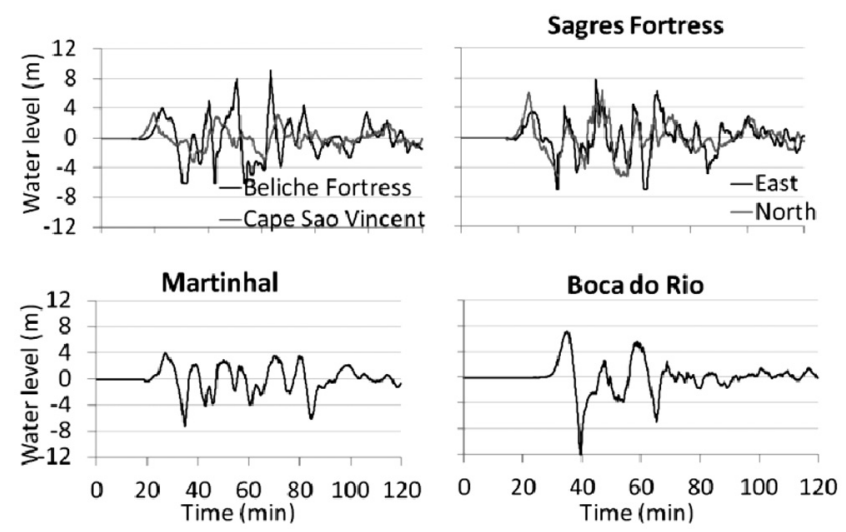

Fig. 7. Water level waveforms at Vila do Bispo.
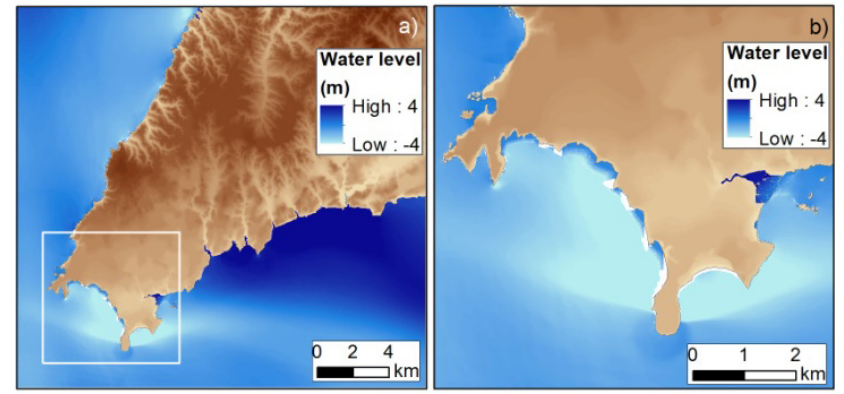

Fig. 8. Tsunami water level snapshot 32 minutes after the earthquake: a) at Vila do Bispo; b) Sagres.

Complete numerical model setting took about six years to complete while handling all of the above conditions and obtaining final results.

\section{Numerical Model Results}

\subsection{Historical Data}

Water-level waveforms (Fig. 7) show that the first tsunami wave, which was $0.11 \mathrm{~m}$ high, reached Cape Sao Vincent at 15 minutes after the earthquake, and that the wave had become $3.41 \mathrm{~m}$ high 20 minutes after the earthquake.

These results, which agree with eyewitness accounts (Table 1), have been validated on a regional scale [2]. Just three major waves over $4 \mathrm{~m}$ high hit Beliche Fortress, although the numerical model produced several waves. The maximum water level on the east side of Sagres Fortress was higher than that on the north side.

At Martinhal, there were also three major waves over $3 \mathrm{~m}$ high, the first being the highest at $3.97 \mathrm{~m}$. These results agree with historical accounts (Table 1).

At Boca do Rio, the first wave was $7 \mathrm{~m}$ high, with a trough $-12 \mathrm{~m}$, which would transport significant amounts of sand, enough to uncover the Roman settlement. A tsunami snapshot 32 minutes after the earthquake, in Fig. 8, shows that the first wave receded and left parts of the bay dry (white areas).

The inundation depth (Fig. 9a) shows that the tsunami
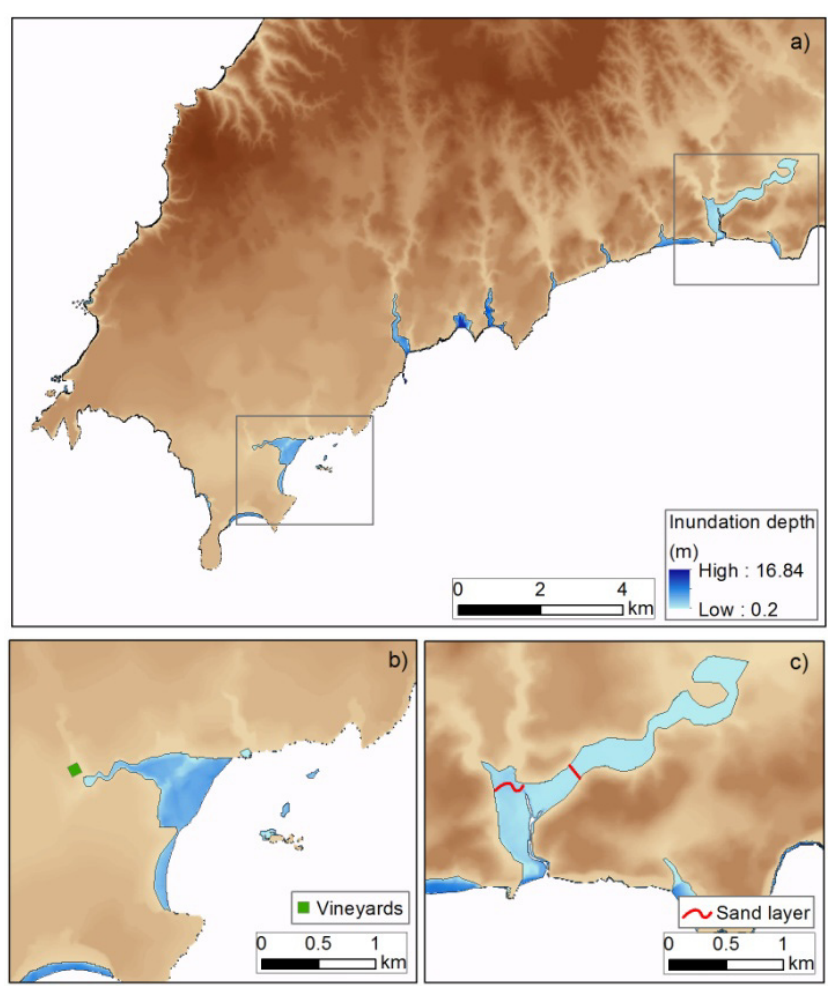

Fig. 9. a) Inundation depth at Vila do Bispo; b) inundation depth detailed at Martinhal and the location of the vineyards; c) inundation depth detailed at Boca do Rio and sand layer limits [21].
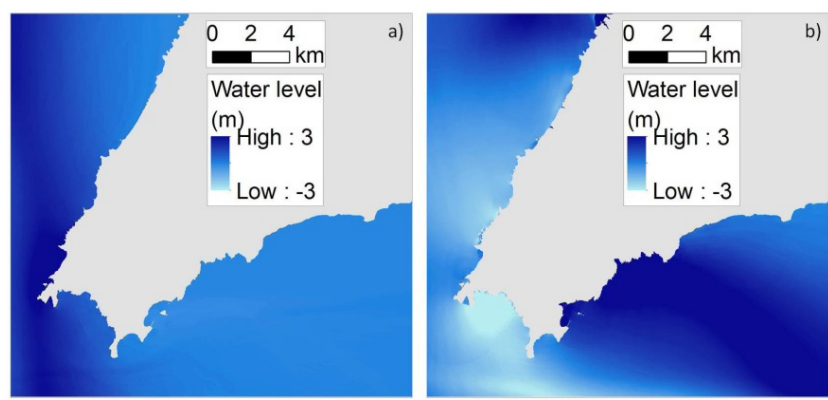

Fig. 10. Snapshots of Water level high: a) 20 minutes and b) 30 minutes.

penetrated inland about $1 \mathrm{~km}$ to Martinhal (Fig. 9b), reaching the vineyards as reported by eyewitnesses (Table 1). It also reached about $1 \mathrm{~km}$ inland in the low Boca do Rio area (Fig. 9c). In contrast, the tsunami reaches about $3 \mathrm{~km}$ inland as reported by the accounts of the time (Table 1). Sediment records only reach about $1.5 \mathrm{~km}$ [21]. Our field survey showed that the area is quite low, i.e., $3 \mathrm{~m}$ high, and has been used as farmland, so sediment records may have been destroyed by continuous scraping and flattening of the land.

\subsection{Modern Data}

The first tsunami wave reaching Vila do Bispo less than 20 minutes after the earthquake was about $3 \mathrm{~m}$ high (Fig. 10a), hitting the entire municipality in less than 30 minutes (Fig. 10b). 

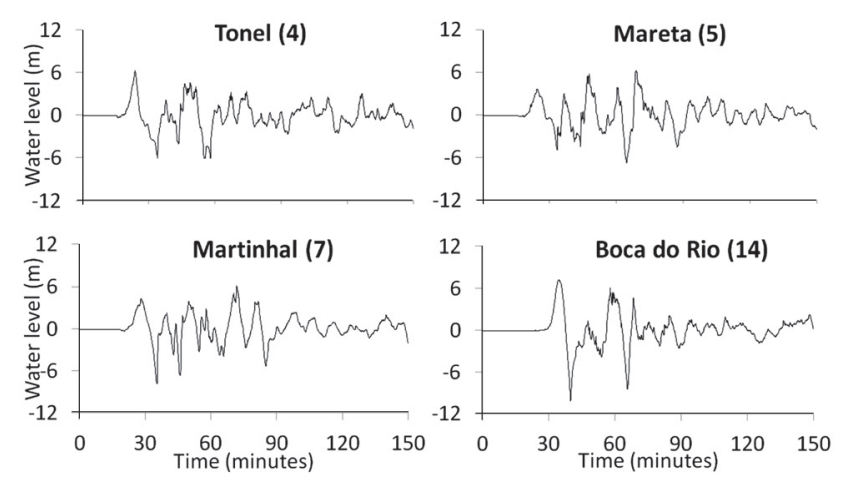

Fig. 11. Water level waveforms.

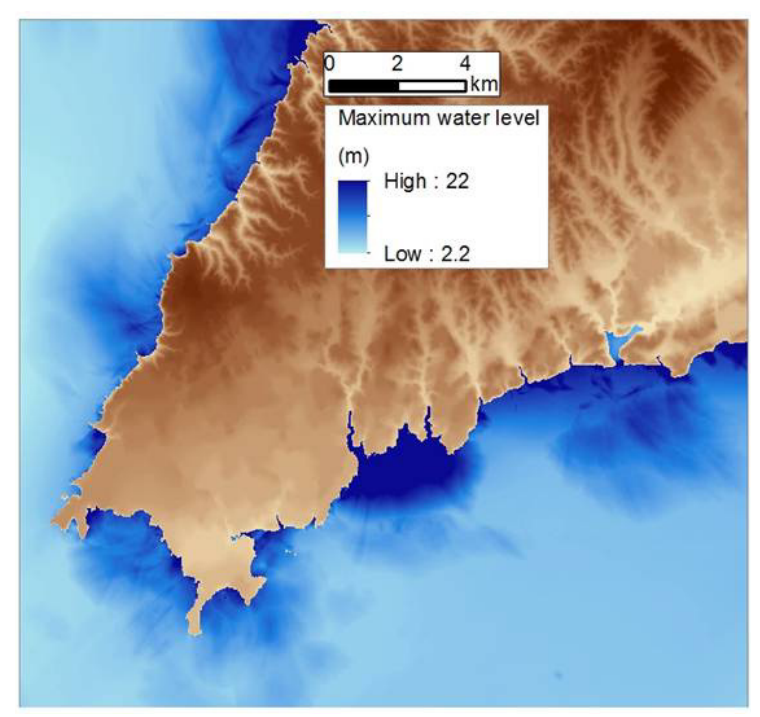

Fig. 12. Maximum water level height.

Water level waveforms (Fig. 11) showed that several waves hit beaches, mostly during the first 90 minutes after the earthquake. There were 3 or 4 waves higher than $3 \mathrm{~m}$ high. At Tonel (4) and Boca do Rio (14), the first wave was the highest, while at Mareta (5) and Martinhal (7), the fourth wave was the highest.

The maximum water level (Fig. 12) showed that tsunami waves exceeded $2 \mathrm{~m}$ in our study area but amplify at the coast, reaching 7-8 $\mathrm{m}$ high. Off the shore of beaches at Barranco (8), Ingrina (9) and Zavial (10), where there is a significant local amplification to $12-16 \mathrm{~m}$, waves reached a maximum of $22 \mathrm{~m}$ high east of Zavial Beach (10).

The inundation depth of the tsunami was 0.5 to $21 \mathrm{~m}$, and all of the beaches and low areas were inundated (Fig. 13). At most beaches, inundation was restricted to the beach, with waves extending inland less than $70 \mathrm{~m}$ because the beaches were surrounded by high cliffs (Castelejo (2), Beliche (3), Tonel (4), Mareta (5) and Burgau (16)). This was also the case at the port of Baleeira (6), where tsunami extended up to $60 \mathrm{~m}$ inland. At Cordoama (1), however, they extended about $230 \mathrm{~m}$, while at Martinhal Beach (7), the tsunami reached almost $1.1 \mathrm{~km}$ inland (Fig. 6b). At Barranco (8), the tsunami reached

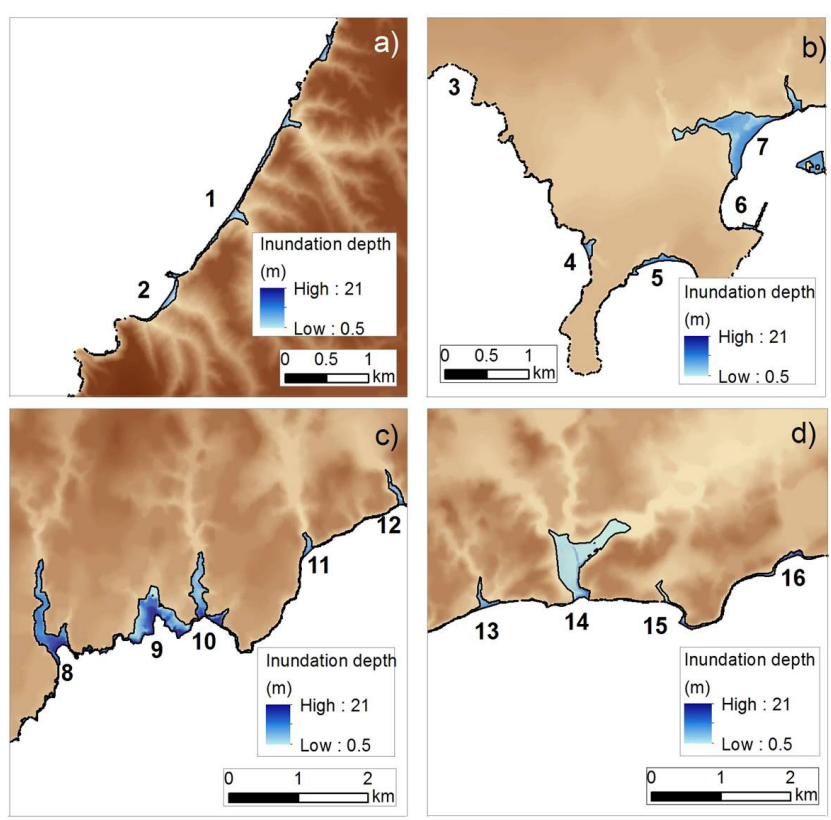

Fig. 13. Inundation depth details at a) Cordoama (1) and Castelejo (2) Beaches; b) Beliche (3), Tonel (4), Mareta (5) and Martinhal (7) Beaches, and at Baleeira Port (6); c) Barranco (8), Ingrina (9), Zavial (10), Furnas (11) and Figueira (12) Beaches; d) Salema (13), Boca do Rio (14), Cabanas Velhas (15) and Burgau (16) Beaches.

$1.5 \mathrm{~km}$ inland, at Ingrina (9) $400 \mathrm{~m}$, at Zavial Beach (10) $930 \mathrm{~m}$, at Furnas (11) $280 \mathrm{~m}$, at Figueira (12) $540 \mathrm{~m}$ (Fig. 6c), at Salema (13) $470 \mathrm{~m}$ and at Cabanas Velhas (15) $360 \mathrm{~m}$.

\section{Tsunami Hazards}

A criterion for tsunami hazard [15] was applied to Vila do Bispo. In the criterion, the susceptibility of water level and travel times are classified into 5 categories (Fig. 14). Numerical model results showed a water level susceptibility between low and high (Fig. 15a), and a travel time susceptibility between moderate and critical (Fig. 15b). We combined these susceptibilities to get a tsunami hazard at a regional scale, also classified into 5 categories, varying between moderate and critical (Fig. 15c).

We conducted a field survey on coastal areas indicated in Fig. 2b, to assess whether an easy evacuation path (EEP) existed. We then combined evacuation conditions with the tsunami hazard classification to obtain the local tsunami hazard (Fig. 15d).

The photos in this study were taken in August 2014. Castelejo Beach (2) has an EEP from the beach to safe high ground (Fig. 16a), and the parking lot is located behind the camera on even higher ground. Beach users would need less than three minutes to reach safe high ground, but would need to act quickly and evacuate the beach immediately after an earthquake, which is why the local tsunami hazard is classified as high (Fig. 15d).

Other places with EEPs were Tonel (4) (Fig. 16b), 
Criterion for Tsunami Hazard Assessment at regional scale

\begin{tabular}{|c|c|c|c|}
\hline $\begin{array}{l}\text { Water level height } \\
\qquad(\mathrm{m})\end{array}$ & Classification & $\begin{array}{l}\text { Travel time } \\
\text { (min) }\end{array}$ & Classification \\
\hline $0-2$ & Very low & $0-20$ & Critical \\
\hline $2-5$ & Low & $20-30$ & High \\
\hline $5-10$ & Moderate & $30-40$ & Moderate \\
\hline $10-15$ & High & $40-50$ & Low \\
\hline More than 15 & Critical & More than 50 & Very low \\
\hline
\end{tabular}

Tsunami Hazard Matrix

\begin{tabular}{|l|c|c|c|c|c|}
\hline $\begin{array}{r}\text { W. L. } \\
\text { height } \\
\text { T. Time }\end{array}$ & Very low & Low & Moderate & High & Critical \\
\hline Critical & Moderate & High & High & Critical & Critical \\
\hline High & Moderate & Moderate & High & High & Critical \\
\hline Moderate & Low & Moderate & Moderate & High & High \\
\hline Low & Low & Low & Moderate & Moderate & High \\
\hline Very low & Very low & Low & Low & Moderate & Moderate \\
\hline
\end{tabular}

Tsunami Hazard Assessment at the local scale

\begin{tabular}{|l|c|c|c|c|c|}
\hline Easy E. Path & Very low & Low & Moderate & High & Critical \\
\hline No & Low & Moderate & High & Critical & Critical \\
\hline Yes & Very low & Low & Moderate & High & Critical \\
\hline
\end{tabular}

Fig. 14. Tsunami hazard assessment on a local scale combining the tsunami hazard and the easy evacuation path (EEP) [15].

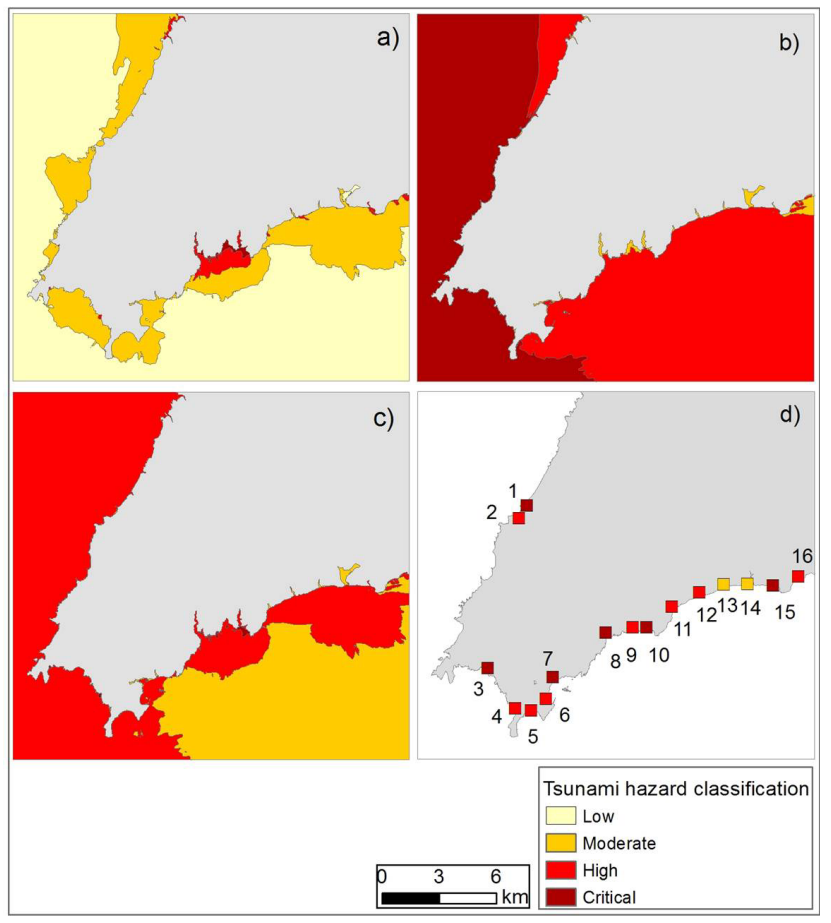

Fig. 15. Tsunami hazard assessment results at Vila do Bispo: a) water level susceptibility; b) travel times susceptibility; c) tsunami hazard; d) tsunami hazard on the local scale.

Mareta Beaches (5) (Fig. 16c), Baleeira Port (6) (Fig. 16d), Ingrina Beach (9) (Fig. 16e) and Burgau (16) (Fig. 16h). As at Castelejo Beach (2), beachgoers would have to act quickly and reach high ground outside the inundation zone in three to five minutes. This is why we classified local tsunami hazards in these areas as high (Fig. 15d). Salema (13) had several roads leading to safe high ground and buildings over 2 stories high (Fig. 16f), which is why we classified the local tsunami hazard as moderate, the same as for Boca do Rio (14), which also had an EEP (Fig. 16g).

In contrast, beaches at Vila do Bispo did not offer an easy safe evacuation, as shown in Fig. 17. Cordoama Beach (1) had safe high ground nearby; the parking lot layout could cause chaos during an evacuation (Fig. 17a) because the beach is quite wide, requiring persons to walk about $200 \mathrm{~m}$ between the shore and the parking lot, which would take more than three minutes. There is no EEP, so we classified the local tsunami hazard as critical (Fig. 15d).

Beliche Beach (3) is surrounded by high cliffs (Fig. 17b), and initial access from the parking lot to the beach (behind the camera) is easy. Below $23 \mathrm{~m}$ high, the path is very difficult and unstable cliffs led us to classify the local tsunami hazard as critical.

Martinhal Beach (7), restaurants and a windsurfing club (Fig. 17c) are located on a low topography of less than $3 \mathrm{~m}$ ), so persons would have to walk about $760 \mathrm{~m}$ to reach safe high ground - an effort that would take about 14 minutes, which is why we classified the local tsunami hazard as critical (Fig. 15d).

Tsunami inundation at Barranco Beach (8) would reach as far as $1.4 \mathrm{~km}$ inland because the area is flat with low topography of less than $5 \mathrm{~m}$ high. The two main hills that persons could conceivably reach, however, have access that is difficult to the top of the hills with a local inundation depth of 11-13 m (Fig. 13c), meaning that evacuation would be extremely difficult, especially for persons who had conducted no drills. Although the parking lot and road are located on low ground (Fig. 17d), it is highly likely that tourists would try to evacuate by car, which would distress drivers, so we classified the local tsunami hazard as critical.

At Zavial Beach (10), the inundation depth was 10$13 \mathrm{~m}$ (Fig. 13c), but field survey results showed the parking lot and road to be only 4.84-6.25 m high (Fig. 17e). Beach users would have to walk over $550 \mathrm{~m}$ to reach safe high ground, which would take about 10 minutes. This means that the local tsunami hazard is critical.

At Furnas Beach (11), the parking lot is located in an inundation zone (Fig. 17f) and the road continues over $500 \mathrm{~m}$ on low ground. The area is surrounded by high hills but has no access to the top, so we classified the local tsunami hazard as high (Fig. 15d).

Figueira Beach (12) has a completely natural landscape, with vegetation and without road access (Fig. 17g), so there is no EEP. During the survey, we needed about 12 minutes to go from the beach to high ground outside of the inundation zone, so the local tsunami hazard is high.

Cabanas Velhas Beach (15) had a restaurant (behind the camera) and the beach entrance itself was quite narrow, and like at Cordoama Beach (1), the parking lot was lo- 


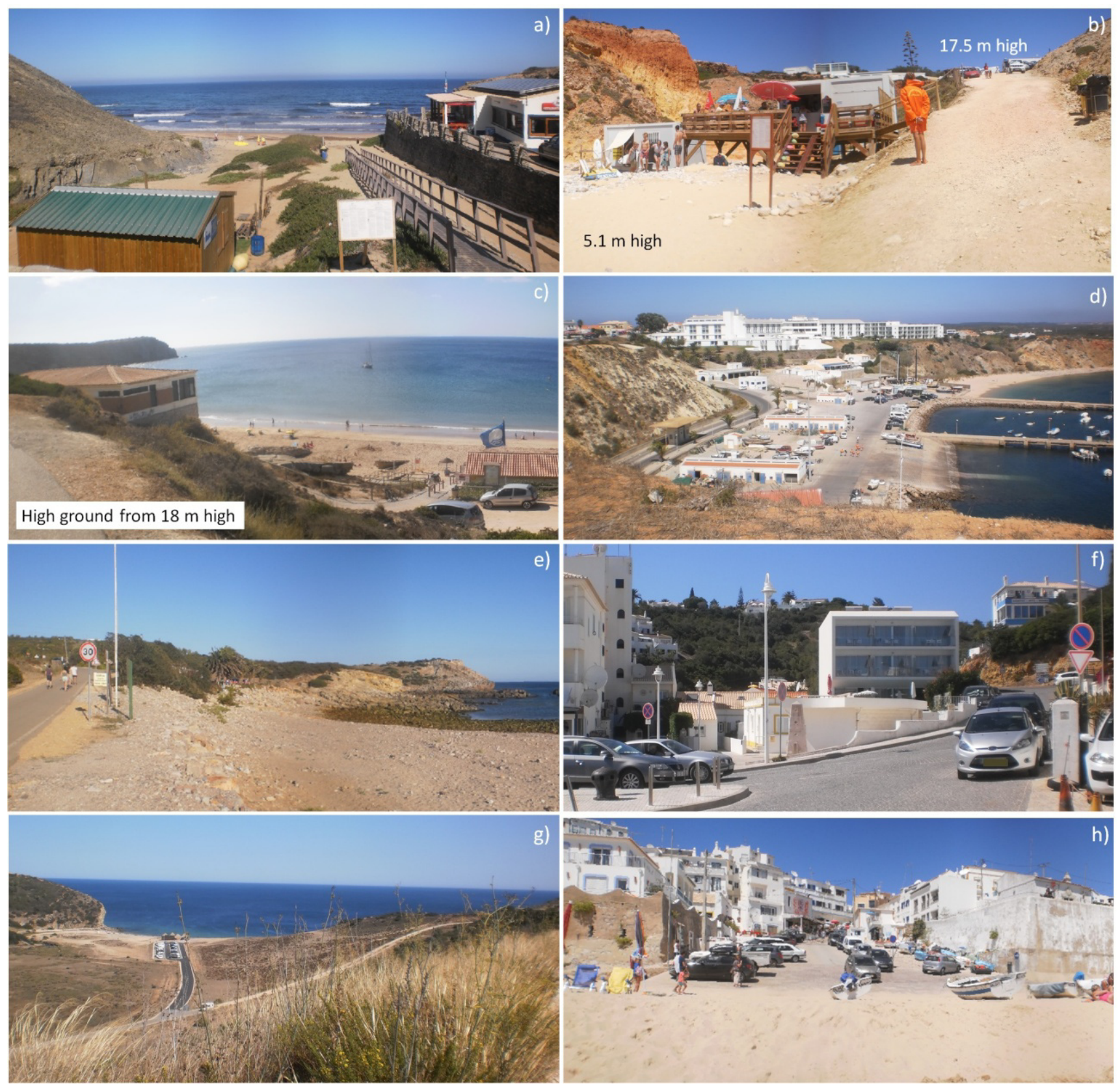

Fig. 16. Beaches with safe high ground nearby and with Easy Evacuation Path (EEP): a) Castelejo (2); b) Tonel (4); c) Mareta (5); d) Baleeira Port (6); e) Ingrina (9); f) Salema (13); g) Boca do Rio (14); h) Burgau (16).

cated on low ground in the inundation zone (Fig. 17h). This might cause chaos during an evacuation. With high ground at least $480 \mathrm{~m}$ away, persons would need at least eight minutes to reach safety, so we classified the local tsunami hazard as critical (Fig. 15d).

\section{Discussion}

In this study, we considered the 1755 Lisbon Tsunami to be the worst scenario for a numerical model. Historical data reproduced overall tsunami parameters described by eyewitnesses at the time. Results showed that the tsunami reached Sao Vincent Cape 14-20 minutes after the earth- quake, which agrees with historical accounts and previous numerical modeling results [2]. Eyewitnesses described water as receding at 6-7 minutes after the earthquake, leaving inlets dry between Cape Sao Vincent and Sagres. It is very likely, however, that the bay was much shallower at the time of the 1755 earthquake, so the numerical model did not accurately reproduce the initial response.

Using historical data, the numerical model, reproduced three major waves at Beliche and Martinhal, as reported by witnesses. The first, at Martinhal, was the largest, which also agreed with historical reports. At Sagres Fortress, the maximum water level at the east is indeed higher than at the north, as reported by witnesses.

At Boca do Rio, the first wave was $7 \mathrm{~m}$ high and the 

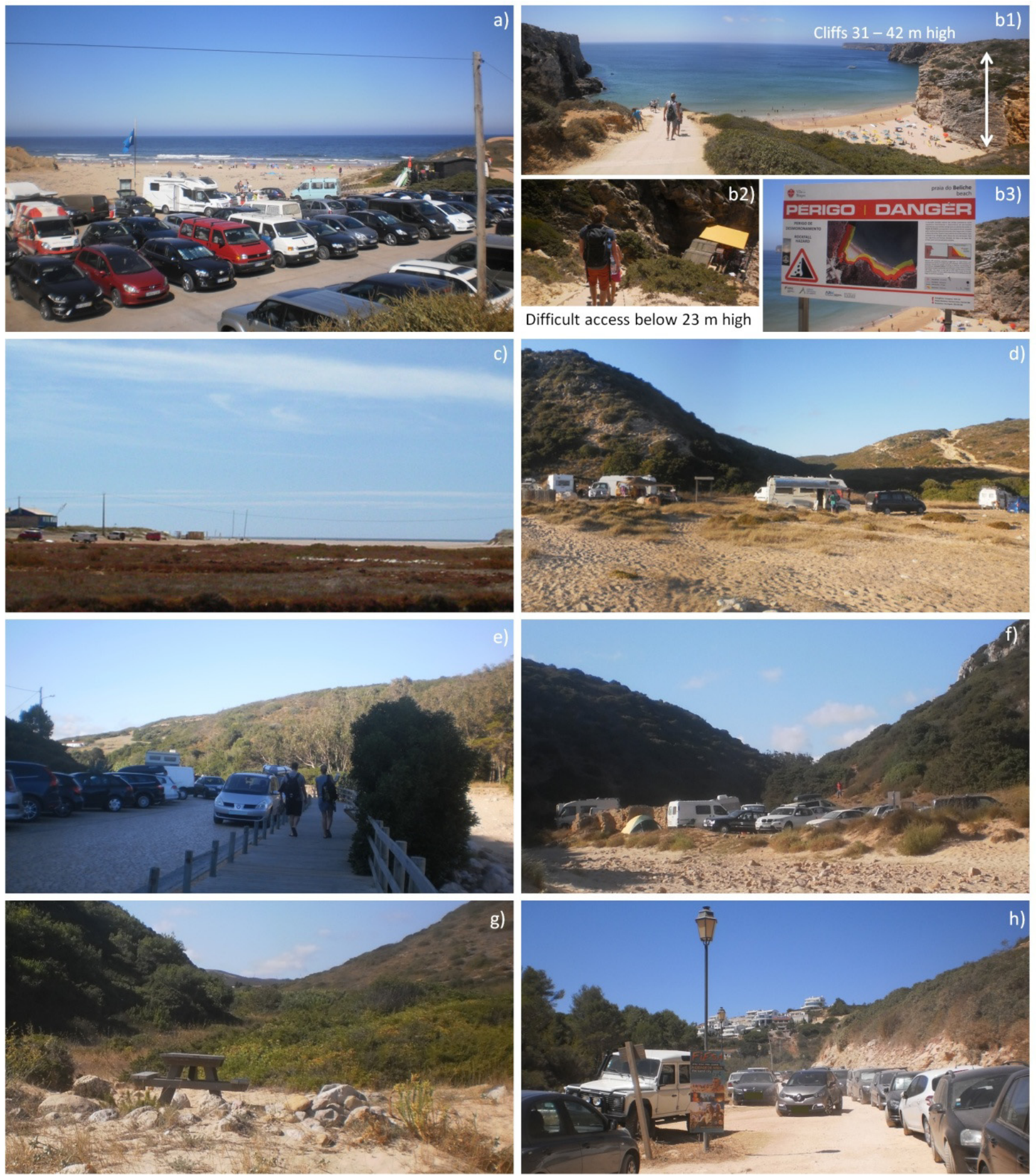

Fig. 17. Vila do Bispo beaches where safe, swift evacuation would likely be difficult: a) Cordoama (1); b) Beliche (3); c) Martinhal (7); d) Barranco (8); e) Zavial (10); f) Furnas (11); g) Figueira (12); h) Cabanas Velhas (15).

trough reached $-12 \mathrm{~m}$, which would transport significant amounts of sand, which would be enough to uncover evidence of the Roman settlement.

Eyewitnesses' accounts reported that the tsunami reaching Beliche Fortress, which is located at a height $54 \mathrm{~m}$ above the fortress, as confirmed by our field survey measurements of $51 \mathrm{~m}$ high. Eyewitnesses also reported extreme tsunami run-up at Sagres Fortress - higher on the eastern side than on the northern side. At Sagres Fortress, the Hercules storm, identified as a meteotsunami [34], confirmed that tsunami waves could indeed break and be amplified significantly at the cliffs. Numerical model results were underestimated at the cliffs because the numerical model did not have a function for the wave breaking 
effect, although local amplifications were obtained.

The inundation depth showed that the tsunami penetrated inland at Boca do Rio and Martinhal, where the tsunami reaches almost $1 \mathrm{~km}$ inland. Although inundation extension was underestimated compared to eyewitness accounts, our field survey showed that the vineyards mentioned in historical accounts still existed and the tsunami would have reached that area. The tsunami reached about $1 \mathrm{~km}$ inland in the low area of Boca do Rio, reaching the approximate location where sediments were found. The tsunami reached about $3 \mathrm{~km}$ inland on the other branch, however, whereas eyewitnesses at the time reported penetration inland exceeding $2250 \mathrm{~m}$. We therefore concluded that the tsunami source model [2] was confirmed validated by historical accounts, geological records and our field survey.

Numerical model results also showed that a tsunami similar to this historical event would reach all Vila do Bispo beaches and low areas within 15-30 minutes of the earthquake, with maximum water levels ranging from 2 to $22 \mathrm{~m}$ high.

Although significant efforts have been carried out in Japan to develop effective near-field tsunami forecasting [50], Portugal has only three real time tide gauge stations $^{2}$, and no effective tsunami warning system has been implemented yet. Portugal also has few tsunamis, with the last registered almost half a century ago in 1969 [22]. These gaps between tsunamis lets persons forget the importance of this type of natural disaster, especially considering that a tsunami would reach Vila do Bispo in less than 20 minutes after an earthquake. We therefore applied a tsunami hazard criterion combining our tsunami numerical model results, i.e., travel time and water level height, with a field survey to assess whether there is an EEP. Our classifications varied between moderate and critical, being high in most of the area studied. Field survey results showed that $50 \%$ of the inundated areas have high cliffs or hills within three to five minutes of walking, providing an EEP. Still, the local tsunami hazard is moderate or high, and affected citizens should evacuate beaches immediately after an earthquake. At $50 \%$ of the beaches, access could hinder safe, swift evacuations, endangering beach users in a tsunami. It is also very likely that many persons would try to evacuate by car, as happened in five towns in Japan during the 2011 Tohoku tsunami [51-55], in the 2009 earthquake in Indonesia [56] and in Hawaii during 2012 Haida Gwaii Tsunami [57].

The Hercules storm [34] showed that many educational activities must lie ahead because despite the early warnings by Portuguese authorities, many Portuguese citizens went to the shoreline to watch the waves, with about 20 persons needing to be rescued. An evacuation exercise conducted at the Lisbon University Campus showed that ordinary citizens are not aware of emergency evacuation safety procedures [26]. This was confirmed by a second study [58]. Still, efforts have been conducted at high schools related to earthquake and tsunami disaster aware-

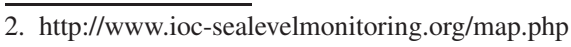

ness [59-61]. Japan's 2011 Tohoku tsunami showed that knowledge about historical events combined with the regular practice of evacuation exercises and drills are crucial for safe, swift evacuations [62,63]. Regular evacuation exercises and drills should thus be implemented, complemented by making tsunami hazard maps available at beaches and areas of low ground.

\section{Acknowledgements}

We thank the Lagos Museum for granting us special permission to take photos of the Roman mosaics of Boca do Rio, and to the Beliche Fortress reconstruction site staff for letting us enter the area. Special thanks also go to Dr. António Pacheco, Prof. Oliveira Marques and Prof. Ana Maria Rodrigues for their invaluable assistance in converting Historical Portuguese Units. We would also like to thank Dr. Francisco Alves (IGESPAR) for his detailed explanations of archeological finds at Boca do Rio and Prof. João Mota Barroso and Dr. João Correia for their informative comments on the vineyards at Martinhal.

This research was supported by the Tsurima Project - Tsunami Risk Management for Spatial Planning and Civil Protection (PTDC/CSGEO/118992/2010) funded by the Foundation of Science and Technology (FCT), Portugal, and by Grants-in-Aid for Scientific Research (25242035).

\section{References:}

[1] A. Santos, "Tsunami Hazard Assessment in Portugal by the Worst Case Scenario: The November 1st, 1755 Lisbon Tsunami," PhD Thesis, Tohoku University, p. 210, 2008.

[2] A. Santos, S. Koshimura, and F. Imamura, "The 1755 Lisbon Tsunami: Tsunami source determination and its validation," Jour. Disaster Research., Vol.4, No.1, pp. 41-52, 2009.

[3] L. Sousa, "O terramoto do $1 .^{\circ}$ de Novembro de 1755 em Portugal e um estudo demografico," Serviços Geológicos, Vol.1, pp. 1-277, 1919.

[4] L. Sousa, "O terramoto do $1 .^{\circ}$ de Novembro de 1755 em Portugal Portugal e um estudo demografico," Serviços Geológicos, Vol.2, pp. 283-472, 1919.

[5] L. Sousa, "O terramoto do $1 .^{\circ}$ de Novembro de 1755 em Portugal e um estudo demografico," Serviços Geológicos, Vol.3, pp. 479-949, 1928.

[6] L. Sousa, "O terramoto do $1 .^{\circ}$ de Novembro de 1755 em Portugal e um estudo demografico," Serviços Geológicos, Vol.4, pp. 955-1013, 1932.

[7] F. Machado, "Contribuição para o estudo do terramoto de 1 de Novembro de 1755," Revista da Faculdade de Ciencias, Universidade de Lisboa, $2^{\mathrm{a}}$ série, C, Vol.XIV - Fasc. 1, pp. 19-31, 1966.

[8] R. Grandin, J. F. Borges, M. Bezzeghoud, B. Caldeira, and F. Carrilho, "Simulations of strong ground motion in SW Iberia for the 1969 February $28(\mathrm{Ms}=8.0)$ and the 1755 November $1(\mathrm{Ms}=8.5)$ earthquakes - II. Strong ground motion simulations," Geophys. J. Int., Vol.171, pp. 807-822, 2007.

[9] I. D. L. Foster, A. J. Albon, K. M. Barbell, J. L. Fletcher, T. C. Jardine, R. J.Mothers, M. A. Pritchard, and S. E. Turner, "High energy coastal sedimentary deposits; an evaluation of depositional processes in Southwest England," Earth Surface Processes and Landforms, Vol.16, pp. 341-356, 1991.

[10] A. Dawson, I. D. L. Foster, S. Shi, D. E. Smith, and D. Long, "The identification of tsunami deposits in coastal sediment sequences," Scie. Tsun. Haz., Vol.9, No.1, pp. 73-82, 1991.

[11] D. Banerjee, A. S. Murray, and I. D. L. Foster, "Scilly Isles, UK: optical dating of a possible tsunami deposit from the 1755 Lisbon earthquake," Quaternary Science Reviews, Vol.20, pp. 715-718, 2001.

[12] J. Thomson and P. P. E. Weaver, "An AMS radiocarbon method to determine the emplacement time of recent deep-sea turbidites," Sedimentary Geology, Vol.89, pp. 1-7, 1994.

[13] S. M. Lebreiro, I. N. McCave, and P. P. E. Weaver, "Late Quaternary Turbidite Emplacement on the Horseshoe Abyssal Plain (Iberian Margin),” Jour. Sed. Res, Vol.67, No.5, pp. 856-870, 1997. 
[14] A. Santos and K. Koshimura, "The historical review of the 1755 Lisbon Tsunami," Jour. Geodesy and Geomatics Eng, Vol.1, pp. 3852, 2015.

[15] A. Santos and S. Koshimura, "A criterion for tsunami hazard assessment at the local scale," Jour. Geodesy and Geomatics Eng, Vol.2, pp. 87-96, 2015.

[16] A. Santos and S. Koshimura, "Tsunami Hazards at Setubal Urban Area Considering the 1755 Lisbon Tsunami," Proc. of the IX C GP, 2013. http://riskam.ul.pt/images/pdf/ix_cgp_santos _koshimura_2013_hazard.pdf [accessed June 2, 2015]

[17] A. Santos, A. O. Tavares, and A. Emidio, "Comparative tsunami vulnerability assessment of an urban area: An analysis of Setúbal city, Portugal," Applied Geography, Vol.55, pp. 19-29, 2014. http://dx.doi.org/10.1016/j.apgeog. 2014.08.009.

[18] S. Kortekaas and A. Dawson, "Distinguishing tsunami and storm deposits: An example from Martinhal, SW Portugal," Sedimentary Geology, Vol.200, pp. 208-221, 2007.

[19] M. Silva, R. Hindosn, and C. Andrade, "Bioerosion evidence of extreme marine flooding of Algarve region (Southern Portugal) associated with the tsunami of the AD 1755 Lisbon Earthquake: Taphonomic and (Paleo) ecological analysis," II Reunion de Tafonomia y fossilizacion, pp. 371-378, 1996.

[20] A. Dawson, R. Hindson, C. Andrade, C. Freitas, R. Parish, and M. Bateman, "Tsunami sedimentation associated with the Lisbon earthquake of 1 November AD 1755: Boca do Rio, Algarve, Portugal," The Holocene, Vol.5, No.2, pp. 209-215, 1995.

[21] R. A. Hindosn and C. Andrade, "Sedimentation and hydrodynamic processes associated with the tsunami generated by the 1755 Lisbon earthquake," Quaternary Int., Vol.56, pp. 27-38, 1999.

[22] M. Baptista and J. Miranda, "Revision of the Portuguese catalog of tsunamis," Nat. Haz. Earth Syst. Sci., Vol.9, pp. 9-25, 2009.

[23] J. Borrero "Field Survey of Northern Sumatra and Banda Aceh Indonesia after the Tsunami and Earthquake of 26 December 2004," Seismo. Res. Letts., Vol.76, No.1, pp. 312-20, 2005.

[24] D. Dominey-Howes, L. Dengler, P. Dunbar, L. Kong, H. Fritz, F. Imamura, B. McAdoo, K. Satake, A. Yalciner, M. Yamamoto, E. Yulianto, S. Koshimura, J. Borrero, Int. Tsunami Survey Team (ITST), "Post-Tsunami Survey Field Guide," UNESCO-IOC, 2nd edition. Paris, 89p., 2012.

[25] F. Imamura, T. Arikawa, T. Tomita, T. Yasuda, and Y. Kawata, "Field Investigation on the 2004 Indian Ocean Tsunami in the Southwestern Coast of Sri Lanka? Sumatra Tsunami on 26th December 2004," Proc. of the Special Asia Tsunami Session at APAC, 93-105, 2005

[26] A. Santos and M. Queirós, "Public buildings safety: Addressing a pilot evacuation exercise," Safety and Reliability: Methodology and Applications, Taylor \& Francis Group, London, pp. 20092015, 2015, http://riskam.ul.pt/images/pdf/santos_queiros_2015.pdf [accessed June 2, 2015]

[27] M. Kobes, I. Helsloot, B. de Vries, J. G. Post, N. Oberijé, and K. Groenewegen, "Way finding during fire evacuation; an analysis of unannounced fire drills in a hotel at night," Building and Environment, Vol.45, pp. 537-548, 2010.

[28] S. Koshimura, H. O. Mofjeld, F. I. González, and A. L. Moore, "Modeling the 1100 bp paleotsunami in Puget Sound, Washington," Geophys. Res. Lett., Vol.29, No.20, pp. 1948, 2002.

[29] K. Satake, K. Wang, and B. F. Atwater, "Fault Slip and Seismic Moment of the 1700 Cascadia Earthquake Inferred from Japanese Tsunami Descriptions," J. Geophys. Res., 108: B11, 2535, 17p., 2003.

[30] A. Oliveira, "Pesos e Medidas," SERRÃO, Joel, Dicionário de História de Portugal, 5, Porto, Livraria Figueirinhas, 67-72, 1985.

[31] J. B. Lopes, "Corografia ou Memória Económica, estatística e Topográfica do Reino do Algarve," Academia Real das Sciencias de Lisboa, 1841.

[32] A. Silva, "Roteiro maritimo da costa occidental e meridional de Portugal," 102pp., 1889

[33] MP- Marinha Portuguesa, Direccao Geral de Farois, "Farois de Portugal," 111pp., Ciencia Viva, 2005.

[34] A. Santos, S. Mendes and J. Corte-Real, "Impacts of the Storm Hercules in Portugal," Finisterra, XLIX, 98, 197-220, 2014, http://revistas.rcaap.pt/finisterra/article/view/6468/4978 [accessed June 2, 2015]

[35] A. Santos, S. Mendes, and J. Corte-Real "Impacts of storm Hercules in southwestern Europe," RIMMA - Risk Information Management, Risk Models, and Applications, Lecture Notes In Science, Vol.7, pp. 39-48, 2015

[36] M. L. Santos, "Arqueologia Romana do Algarve," 404p., Licence Degree Thesis, Lisbon University, 1971.

[37] F. Alves, "Em torno dos projectos da Boca do rio e do Ocean," Setubal Arqeuologica, Vol.11-12, pp. 225-239, 1997.

[38] J. Bernades, "Boca do Rio, 130 ano depois," Actas do 4 Encotnro Arqueologia do Algarve, pp. 341-354, 2003.
[39] A. R. Carrasco, Ó. Ferreira, A. Matias, and J. A. Dias, "Historic Monuments Threatened by Coastal Hazards at Boca do Rio, Algarve, Portugal," Coastal Management, Vol.35, No.2, pp. 163-179, 2007.

[40] A. Johnston, "Seismic moment assessment of earthquakes in stable continental regions - III. New Madrid 1811-1812, Charleston 1886 and Lisbon 1755," Geophys. J. Int., Vol.126, pp. 314-344, 1996.

[41] F. Imamura, "Review of tsunami simulation with a finite difference method," Long Wave runup models, World Scientific, pp. 25-42, 1995.

[42] Y. Okada, "Surface Deformation due to Shear and Tensile Faults in a Half Space," Bull. Seismol. Soc. Am., Vol.75, No.4, pp. 1135 $1154,1985$.

[43] S. Koshimura, T. Oie, H. Yanagisawa, and F. Imamura, "Developing fragility functions for tsunami damage estimation using numerical model and post-tsunami data from Banda Aceh, Indonesia," Coastal Engineering Journal, Vol.51, No.3, pp. 243-273, 2009.

[44] A. Santos and S. Koshimura, "Inundation at Boca do Rio site due to the 1755 Lisbon Tsunami,' Tohoku Branch of the Japan Society of Civil Engineering, 2008.

[45] GEBCO Digital Atlas, General Bathymetric chart of the Oceans, British Oceanographic Data Centre, 2003.

[46] IH - Instituto Hidrografico, Int. bathymetric chart of the Central and Eastern Atlantic, sheet 1.01, 2001.

[47] IH - Instituto Hidrográfico, CSIOAN, 24P05, 24P06, 2009.

[48] IGeoE - Instituto Geográfico do Exército, CMP, 592, 601, 602, 609, 2005.

[49] IGeoE - Instituto Geográfico do Exército, CMP, 593, 2006.

[50] H. Tsushima and Y. Ohta, "Review on Near-Field Tsunami Forecasting from Offshore Tsunami Data and Onshore GNSS Data for Tsunami Early Warning," Jour. Disaster Research, Vol.9, No.3, pp. 339-357, 2014

[51] NHK Morioka, "On that day, on that time: an account from Tarou Kunimitsu san, age 52, at Yamada," NHK Morioka online, broadcasted on 2011 Jul 6 (in Japanese).

[52] NHK Morioka, 2011b. "On that day, on that time: an account from Komukai Aso san, age 60, at Tarou," NHK Morioka online, broadcasted on $2011 \mathrm{Jul} 28$ (in Japanese).

[53] NHK Morioka, "On that day, on that time: an account from Koishi Koetsu san, age 64, at Otsuchi," NHK Morioka online, broadcasted on 2011 Jun 29 (in Japanese).

[54] NHK Morioka, "On that day, on that time: an account from Oikawa Masami san, age70, at Ofunato," NHK Morioka online, broadcasted on 2011 Aug 8 (in Japanese).

[55] NHK Morioka, "On that day, on that time: an account from Tashiro Saiko san, Age71, at Kamaishi," NHK Morioka online, broadcasted on 2011 Sep 5 (in Japanese).

[56] F. Imamura and K. Imai, "Characteristics and Mitigation Measures for Tsunamis Generated Along the Nankai trhough," Jour. Disaster Research, Vol.7, No.1, pp. 127-134, 2012

[57] A. Santos, A. O. Tavares, and M. Queirós, "Numerical modelling and evacuation strategies for tsunami awareness: lessons from the 2012 Haida Gwaii Tsunami," Geomatics, Natural Hazards and Risk, 2015.

[58] A. Santos and M. Queirós, "Risk communication at university campus," III Int. Congress, Guimarães, Portugal, 5 pp, 2014. https://digitalis.uc.pt/en/livro/risk_communication_university _campus [accessed June 2, 2015]

[59] A. Santos, A. Machado and P. Fernandes, "Tsunami pamplet for high school students," 2013 (in Portuguese), https://sites. google.com/a/campus.ul.pt/tsurima/education [accessed June 2, 2015]

[60] A. Santos, P. Fernandes, and L. Carvalho, "Tsunami booklet for elementary school students," 2015 (in Portuguese), https://sites. google.com/a/campus.ul.pt/tsurima/education [accessed June 2, 2015]

[61] A. Machado, "Perceção do risco e implementação de uma cultura de segurança: construindo comunidades educativas resilientes," Master Thesis, Lisbon University, 114p., 2012.

[62] S. Koshimura, S. Hayashi, and H. Gokon, "Lessons from the 2011 Tohoku Earthquake Tsunami Disaster," Jour. Disaster Research, Vol.8, No.4, pp. 549-560, 2013.

[63] A. Santos and M. Queirós, "The 2011 Tohoku Tsunami: analyzing the evacuation of the survivors," IGU Regional Conf., 2013, http://riskam.ul.pt/images/pdf/igu_abstracts_survivors.pdf [accessed June 2, 2015] 


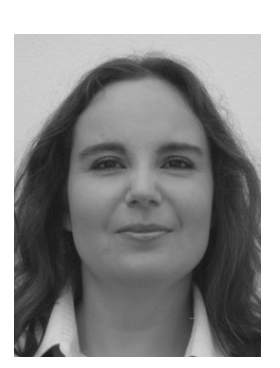

Name:

Angela Santos

\section{Affiliation:}

Researcher, Centre for Geographical Studies, Institute of Geography and Spatial Planning, Universidade de Lisboa

\section{Address:}

Rua Branca Edmée Marques, 1600-276 Lisboa, Portugal

\section{Brief Career:}

2003-2008 MEXT fellow, Tohoku University

2009-2010 Researcher, Centre of Geophysics of Evora, Evora University 2010- Researcher, Centre for Geographical Studies, Institute of Geography and Spatial Planning, Universidade de Lisboa

\section{Selected Publications:}

- A. Santos, A. O. Tavares, and M. Queirós, "Numerical modelling and evacuation strategies for tsunami awareness: lessons from the 2012 Haida Gwaii Tsunami," Geomatics, Natural Hazards and Risk, 2015.

- A. Santos, A. O. Tavares, and A. Emidio, "Comparative tsunami vulnerability assessment of an urban area: An analysis of Setúbal city, Portugal," Applied Geography, Vol.55, pp. 19-29, 2014.

- A. Santos, S. Koshimura, and F. Imamura, "The 1755 Lisbon Tsunami: Tsunami source determination and its validation," Journal Disaster Research, Vol.4, No.1, pp. 41-52, 2009.

Academic Societies \& Scientific Organizations:

- Japan Society of Civil Engineers (JSCE)

- Portuguese Association of Risk, Prevention and Safety (RISCOS)

- International Council of Science (ICSU, UNISDR)

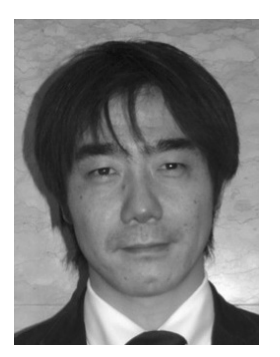

Name:

Shunichi Koshimura

\section{Affiliation:}

Professor, International Research Institute of Disaster Science, Tohoku University

\section{Address:}

Aoba 6-6-03, Aramaki, Aoba-Ku, Sendai 980-8579, Japan

Brief Career:

2000-2002 JSPS Research Fellow

2002-2005 Research Scientist, Disaster Reduction and Human Renovation Institute

2005-2012 Associate Professor, Graduate School of Engineering, Tohoku University

2012- Professor, International Research Institute of Disaster Science,

Tohoku University

\section{Selected Publications:}

- E. Mas, B. Adriano, and S. Koshimura, "An Integrated Simulation of Tsunami Hazard and Human Evacuation in La Punta, Peru," Journal of Disaster Research, Vol.8, No.2, pp. 285-295, 2013.

- S. Koshimura, T. Oie, H. Yanagisawa, and F. Imamura, "Developing fragility functions for tsunami damage estimation using numerical model and post-tsunami data from Banda Aceh, Indonesia," Coastal Engineering Journal, JSCE, Vol.51, No.3, pp. 243-273, 2009.

- S. Koshimura, Y. Namegaya, and H. Yanagisawa, "Tsunami Fragility - A new measure to assess tsunami damage," Journal of Disaster Research, Vol.4, No.6, pp. 479-488, 2009.

Academic Societies \& Scientific Organizations:

- Japan Society of Civil Engineers (JSCE)

- Institute of Social Safety Science

- Japan Association for Earthquake Engineering (JAEE)

- Japan Society for Computational Engineering and Science (JSCES)

- American Geophysical Union (AGU) 